Article

\title{
The Role of Copper (II) on Kininogen Binding to Tropomyosin in the Presence of a Histidine-Proline-Rich Peptide
}

\author{
Anna Maria Santoro ${ }^{1}\left(\mathbb{D}\right.$, Stefania Zimbone $^{1}$, Antonio Magrì ${ }^{1}\left(\mathbb{D}\right.$, Diego La Mendola ${ }^{2, *}$ (D) and \\ Giulia Grasso 1,*(D) \\ 1 CNR Istituto di Cristallografia Sede Secondaria di Catania, Via Gaifami 18, 95126 Catania, Italy; \\ annamaria.santoro@cnr.it (A.M.S.); stefania_zimbone@libero.it (S.Z.); leotony@unict.it (A.M.) \\ 2 Dipartimento di Farmacia, Università di Pisa, Via Bonanno Pisano 6, 56126 Pisa, Italy \\ * Correspondence: lamendola@farm.unipi.it (D.L.M.); giulia.grasso@cnr.it (G.G.)
}

Received: 14 November 2020; Accepted: 3 December 2020; Published: 8 December 2020

\begin{abstract}
The antiangiogenic activity of the $\mathrm{H} / \mathrm{P}$ domain of histidine-proline-rich glycoprotein is mediated by its binding with tropomyosin, a protein exposed on endothelial cell-surface during the angiogenic switch, in presence of zinc ions. Although it is known that copper ion serum concentration is significantly increased in cancer patients, its role in the interaction of $\mathrm{H} / \mathrm{P}$ domain with tropomyosin, has not yet been studied. In this paper, by using ELISA assay, we determined the modulating effect of TetraHPRG peptide, a sequence of 20 aa belonging to H/P domain, on the binding of Kininogen (HKa) with tropomyosin, both in absence and presence of copper and zinc ions. A potentiometric study was carried out to characterize the binding mode adopted by metal ions with TetraHPRG, showing the formation of complex species involving imidazole amide nitrogen atoms in metal binding. Moreover, circular dichroism showed a conformational modification of ternary systems formed by TetraHPRG, HKa and copper or zinc. Interestingly, slight $\mathrm{pH}$ variation influenced the HKa-TetraHPRG-tropomyosin binding. All these results indicate that both metal ions are crucial in the interaction between TetraHPRG, tropomyosin and HKa.
\end{abstract}

Keywords: tropomyosin; kininogen; copper; zinc; angiogenesis; histidine-proline-rich glycoprotein; circular dichroism

\section{Introduction}

The histidine-proline-rich glycoprotein (HPRG/HRG) is a single chain $(75 \mathrm{kDa})$ protein, produced by the liver and present at high concentrations in plasma of vertebrates. It is characterized by a multi domain structure enabling to interact with various ligands, including heparin [1], phospholipids [2], plasminogen [3], fibrinogen [4], immunoglobulin [5], heme [6], and metals [7]. The ability of HPRG to interact simultaneously with various ligands has suggested [8]. It can act as an adaptor molecule in the modulation of the immune, vascular, and coagulation systems, as well as regulating important processes such as cell adhesion, coagulation, fibrinolysis and angiogenesis [2].

The antiangiogenic activity of HPRG has been brought back to the specific interaction of its His/Pro rich domain $(\mathrm{H} / \mathrm{P})$ to tropomyosin exposed on the surface of endothelial cells during angiogenic switch. Tropomyosin is part of the actin cytoskeleton and it is present on the surface of proliferating activated endothelial cells during the angiogenic switch, representing a receptor for multiple anti-angiogenic proteins [9], to which belong another evolutionarily and structurally related protein, the high molecular weight kininogen (HKa).

Indeed the HPRG displays a high affinity to tropomyosin, $(\mathrm{Kd} \sim 2.5 \mathrm{nmol} / \mathrm{L})[10,11]$ and the binding is further favored by mildly acidic conditions $(\mathrm{pH}<6.5)$, such as those observed within a tumor 
hypoxic region. The unusually high content of histidine residues (pKa, 6.5), (13\% of its total amino acid content) [12] confers to the protein a $\mathrm{pH}$ sensor activity due to the recognition of negatively charge molecules [12].

HPRG, through its $\mathrm{H} / \mathrm{P}$ domain, acquires a positive net charge upon exposure to acidic environments, that result crucial in its complex recognition abilities. The $\mathrm{H} / \mathrm{P}$ domain appears to interact with negatively charged tropomyosin only when the $\mathrm{H} / \mathrm{P}$ domain displays a total positive charge either through binding to $\mathrm{Zn}^{2+}$ via non-charged histidine residues, or by direct protonation of histidine residues induced under mild acidic conditions [10], suggesting a relevant electrostatic contribution to this binding. The $\mathrm{H} / \mathrm{P}$ domain consists of conserved 12 tandem repeats encompassing the five amino acid sequences $(\mathrm{G}) \mathrm{HHPH}(\mathrm{G})$. This region has been investigated [11] and the shorter sequence Ac-(HHPHG) $)_{4}-\mathrm{NH}_{2}$ has been considered an effective HPRG mimic system being able to inhibit angiogenesis [13], as well demonstrated. The previous mentioned $\mathrm{HKa}$, also requires a direct binding to tropomyosin to produce antiangiogenic activity, and it is characterized by a domain (D5) that shows a high similarity with H/P of HPRG suggesting analogous functions. In particular, both HKa-D5 and H/P domain of HPRG display a primary sequence rich of positive charges and lack of disulfide bonds that favor the binding to heparin and zinc ions [14]. Indeed, both these domains mediate the binding to endothelium which is in turn favored by elevated concentrations of $\mathrm{Zn}^{2+}$ released from activated platelets. The latter increase particularly in number in plasma cancer patients causing thrombotic occlusion of vessels. The levels of free $\mathrm{Zn}^{2+}$ in plasma are tightly regulated and are usually too low to promote binding of HPRG to endothelial cells. However during coagulation, the activated platelets release free $\mathrm{Zn}^{2+}$ from $\alpha$-granules [15], and the local concentration of metal ions reaches the levels (approximately 10-50 $\mu \mathrm{mol} / \mathrm{L}$ ) needed to support the binding of HPRG to tropomyosin on endothelial cells. This interaction is believed essential to mediate the HPRG antiangiogenic effects.

Several investigations suggest that in addition to $\mathrm{Zn}^{2+}$ also $\mathrm{Cu}^{2+}$ levels dysregulation are related with cancer [16,17]. Furthermore copper is a well-known angiogenic factor [18], which serum concentration is significantly increased in patients affected by cancers including lymphoma, reticulum cell sarcoma, bronchogenic and laryngeal squamous cell carcinomas, cervical, breast, stomach, and lung cancers $[19,20]$. Noteworthy, the copper levels are related with the stage of the disease and useful to predict relapse and response to therapy [17]. The level of serum copper decreased during periods of remission, sometimes reaching normal levels, and then it rebounded to pre-therapy levels during relapses. It is to note that, unlike copper, the levels of zinc, iron, and selenium are often lower in the serum of cancer patients [21-24]. In fact, the $\mathrm{Cu} / \mathrm{Zn}, \mathrm{Cu} / \mathrm{Fe}$, and $\mathrm{Cu} / \mathrm{Se}$ ratios all appear to be better indicators of the presence of cancer than $\mathrm{Cu}, \mathrm{Zn}, \mathrm{Fe}$, or Se levels alone [21]. Copper is the only metal ions mobilized in endothelial cells during angiogenic processes [25]. This could explain the excess of copper ions found in the extracellular space of tumor cells that use angiogenesis to develop and grow [26].

In this paper, the multiple analogies between copper and zinc, led us to evaluate the potential effect of copper ions in the interaction of the peptide fragment [Ac-(GHHPH) $)_{4}-\mathrm{G}_{-}-\mathrm{NH}_{2}$ ] (TetraHPRG) belonging to $\mathrm{H} / \mathrm{P}$ domain of HPRG, with HKa/tropomyosin.

We used a blocked peptide to $\mathrm{N}$ - and $\mathrm{C}$ - termini [11] to proper mimic a protein fragment and the role of zinc and copper ions in the interaction with tropomyosin was explored by means of ELISA assay and conformational analysis by circular dichroism (CD). Furthermore, the complex formation of $\mathrm{Zn}^{2+}$ TetraHPRG was compared to that of $\mathrm{Cu}^{2+}$ by means of potentiometric study [27], to assess the relevance of $\mathrm{pH}$ and metal complex species in HKa/Tropomyosin/TetraHPRG binding.

\section{Results}

\subsection{Tropomyosin/HKa Binding: In Presence of TetraHPRG, $\mathrm{Cu}^{2+}$ or $\mathrm{Zn}^{2+}$}

To unveil the role of copper ions in the interaction between TetraHPRG and tropomyosin, an ELISA assay was carried out. In the experimental procedure, the plate was coated by human cardiac tropomyosin, while HKa* and the TetraHPRG were added in buffer as competitive agents. 
Differently from a similar assay previously reported [11], here we verified the effect of some experimental variables, such as the $\mathrm{pH}$ and order of addition of reagents (see Methods section) that deeply influenced the amounts of $\mathrm{HKa}^{*}$ detected.

As first step, performing a dose-response curve, the saturation concentration of biotinilated-HKa $\left(\mathrm{HKa}^{*}\right)$ was determined. The minimal concentration of $\mathrm{HKa}^{*}$, able to produce the highest signal obtainable by its binding to tropomyosin, was $80 \mathrm{nM}$.

Successively, the ability of TetraHPRG to compete with $\mathrm{HKa}^{*}$ in the binding with tropomyosin has been tested through the coincubation of TetraHPRG, at different concentrations and maintaining $\mathrm{HKa}^{*}$ concentration set to $80 \mathrm{nM}$. In the concentration range investigated (5-50 $\left.\mu \mathrm{M}\right)$, the TetraHPRG induced a mild reduction of the levels of $\mathrm{HKa}^{*}$ bound to tropomyosin, confirming that the peptide, although at different orders of magnitude, has affinity to tropomyosin and may compete with $\mathrm{HKa}^{*}$.

On the contrary, the shorter sequence i.e., the hexapeptide, encompassing only one repeat unit Ac-GHHPHG- $\mathrm{NH}_{2}$, has no effect, even at $100 \mu \mathrm{M}$, that correspond to $25 \mu \mathrm{M}$ concentration of TetraHPRG.

The metal effect was evaluated using copper or zinc ions at $10 \mu \mathrm{M}$. As showed in Figure 1, in the presence of both metal ions, the TetraHPRG resulted to be not competitive in the binding to tropomyosin; on the contrary, we could notice an increase of $\mathrm{HKa}^{*}$ bound. Therefore, the dose-response trend observed in Figure 1 clearly indicates, that the TetraHPRG, in the used experimental conditions, promoted the tropomyosin-HKa* interaction, suggesting the presence of a ternary system due to the interaction among proteins, peptide and metal ions.

Furthermore, it should be highlighted that in absence of TetraHPRG, the behavior of zinc and copper is opposite; i.e., the $\mathrm{Zn}^{2+}$ slightly reduced the amount of $\mathrm{HKa}^{*}$ bound to tropomyosin, on the contrary, the $\mathrm{Cu}^{2+}$ slightly increased it.

A hypothesis is that the metal ions differently affected the conformational features of molecules involved in the tropomyosin-TetraHPRG-HKa* interaction. Previously, it was reported that the binding of zinc to domain D5 (HKa domain 5) induced a conformational change in the entire HKa molecule [28], unlike other metal ions, as well as $\mathrm{Cu}^{2+}$. Thus, CD measurements were carried out to assess if a similar effect is observed for the investigated systems.

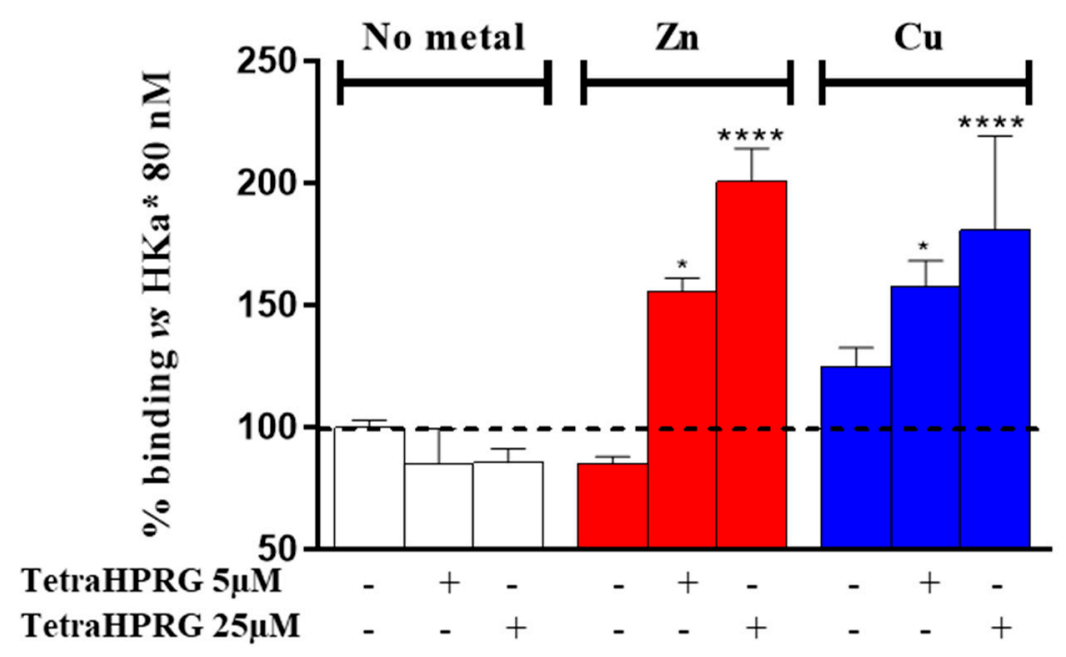

Figure 1. Binding rate of $\mathrm{HKa}^{*}$ at $80 \mathrm{nM}$ in MOPS $\mathrm{pH}$ 7.5. Dose response effect of tetra repeat in coincubation in presence or $\mathrm{Zn}^{2+}$ or $\mathrm{Cu}^{2+}(10 \mu \mathrm{M})$. Data are the mean \pm SEM of three different experiments performed in triplicate. Statistically significant differences are indicated with $*=p<0.05$ and $^{* * * *}=p<0.0001$ vs. HKa $80 \mathrm{nM}$ (One-Way ANOVA + Dunnett's test). 
CD is largely used to study the secondary structure of proteins and peptides [29-32] with the advantage to use low sample concentration and give information also on the effect of added ligands.

First of all, the effect of each metal ions addition to peptide (named binary systems) conformation was explored (Figure 2a,b). Taking into account the high number of proline residues, the CD spectrum features of TetraHPRG may result from an equilibrium among PPII, random coil and $\beta$-turn conformations [33]. The presence of PPII conformation was supported by the CD spectrum that showed a broad minimum at $199 \mathrm{~nm}$ and a slightly negative at about $233 \mathrm{~nm}$ [34,35]. Interestingly, the addition of copper sulphate induced changes in the peptide dichroic signals, while the band at $199 \mathrm{~nm}$ decreased, the band at $233 \mathrm{~nm}$ inversely increased (Figure 2a). The conformational modifications are more evident at increasing amount of copper ions equivalent.
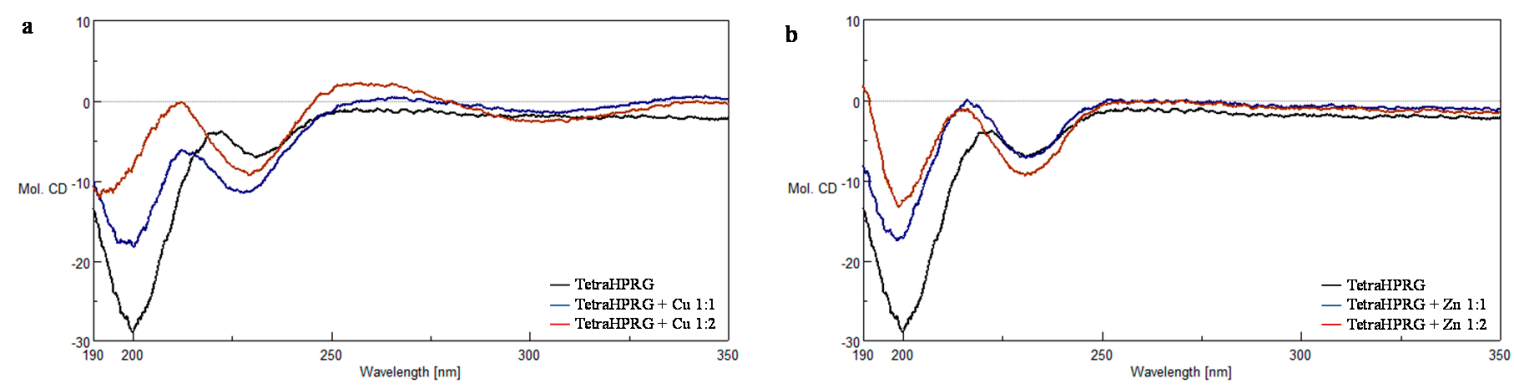

Figure 2. Circular dichroism (CD) spectra of (a) copper (II) and (b) zinc (II) complexes with TetraHPRG in water $(\mathrm{pH}=7.5)$, at different mol equivalent of metal to ligand molar ratio is $1: 1$ and $\left.2: 1 ;[\mathrm{L}]=1 \times 10^{-5} \mathrm{M}\right)$.

Moreover, the peptide/copper(II) spectra showed the appearance of a signal at about $260 \mathrm{~nm}$, that can be assigned to the charge transfer band $\mathrm{N}_{\mathrm{im}} \rightarrow \mathrm{Cu}^{2+}$, and a weak negative band around $300 \mathrm{~nm}$, hallmark of the charge transfer transitions of deprotonated amide nitrogen atoms toward metal ions, $\mathrm{N}^{-}$amide $\rightarrow \mathrm{Cu}^{2+}$ [36]. These results showed the involvement of the histidine residues in the copper coordination environment.

The CD spectra TetraHPRG carried out after the addition of zinc(II) are reported in Figure $2 b$. The perturbation of the ligand conformation due to the addition of the metal ions was different than that observed for the analogous complex with copper, suggesting a more structured conformation of peptide induced by zinc binding.

The speciation and stability constant values for copper complexes formed with TetraHPRG have been reported [27]. Therefore, potentiometric titrations were carried out to determine zinc complex species formation with TetraHPRG and to compare with those obtained for copper ions.

The protonation constants are reported in Table S1. Because of the high number of histidine residues in the primary sequence not all protonation constants were determined [27]. The differences between the $\mathrm{pK}$ values are small and the deprotonation processes take place in overlapping equilibria. Therefore, each protonation constant ha to be considered as a macro-constant and not assigned to a specific histidine residue $[37,38]$. The obtained $\mathrm{pK}$ values are in line with those reported for poly-histidine peptides [39]. The stability constant values of zinc complexes species are listed in Table 1 and the distribution diagram is reported in Figure 3. Measurements were carried out at different metal to ligand molar ratios ranging from 0.5:1 to 2:1 (see supporting materials). Mononuclear complex species are present only at 0.5:1 metal to ligand molar ratio. Increasing the metal to ligand molar dinuclear complex species were formed. (see Figure S1). 
Table 1. Stability constants $(\log \beta)$ and $\mathrm{pK}$ values of the $\mathrm{Zn}^{2+}$ complexes with TetraHPRG $(\mathrm{L})(\mathrm{T}=298 \mathrm{~K}$, $\left.\mathrm{I}=0.1 \mathrm{M} \mathrm{KNO}_{3}\right)^{1}$.

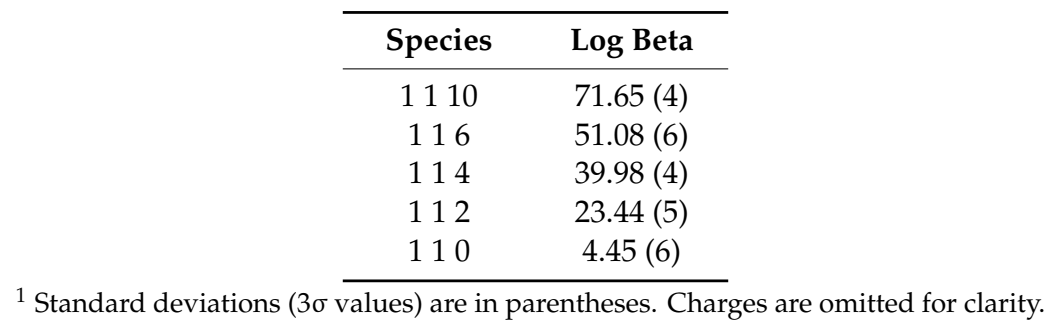

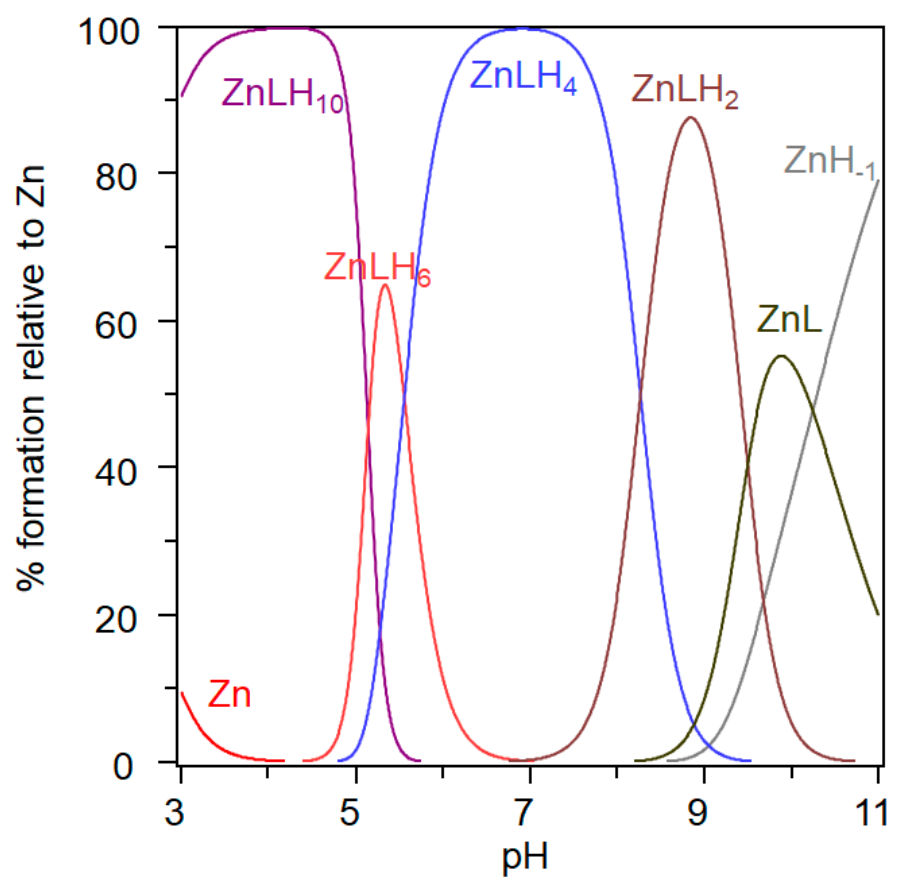

Figure 3. Species distribution diagram for the $\mathrm{Zn}^{2+}$ complexes with TetraHPRG at 0.5:1 (M:L) molar ratio. $\left[\mathrm{Zn}^{2+}\right]=1 \times 10^{-3} \mathrm{M}$.

During potentiometric measurements of $\mathrm{Zn}^{2+}$ complexes, His residues deprotonate in a short $\mathrm{pH}$ range and probably some in pairs in an overlapping mode due to closest values of their $\mathrm{pK}$ value [27].

The predominant zinc complex species formed in the $\mathrm{pH}$ range 6-8 is $\mathrm{ZnLH}_{4}$. Taking into account the deprotonation steps and the stability constant value it is possible to suggest the coordination of four imidazole nitrogen atoms to zinc ion [40-44]. In the $\left[\mathrm{ZnLH}_{2}\right]$ complex species the further deprotonation steps most probably come from other histidine residues which do not participate in binding even though the involving of amide nitrogen peptide backbone has been reported [45].

Increasing the equivalent of zinc ions, dinuclear species were detected. However, either at 1:1 or at 2:1 metal to ligand molar ratio, precipitation phenomenon occurred starting from $\mathrm{pH} 5$, so it was not possible to determine with sufficient accuracy the stability constant values of complex species containing two zinc ions (see supplementary Figure S1).

The CD spectrum of the HKa/TetraHPRG binary system is reported in Figure 4. The HKa protein showed a weaker intensity of dichroic signals respect to those of peptide alone. No significative conformational differences were observed when TetraHPRG was added to HKa, indicating that they did not interact significantly, in agreement with ELISA assay results (see Figure 2). 


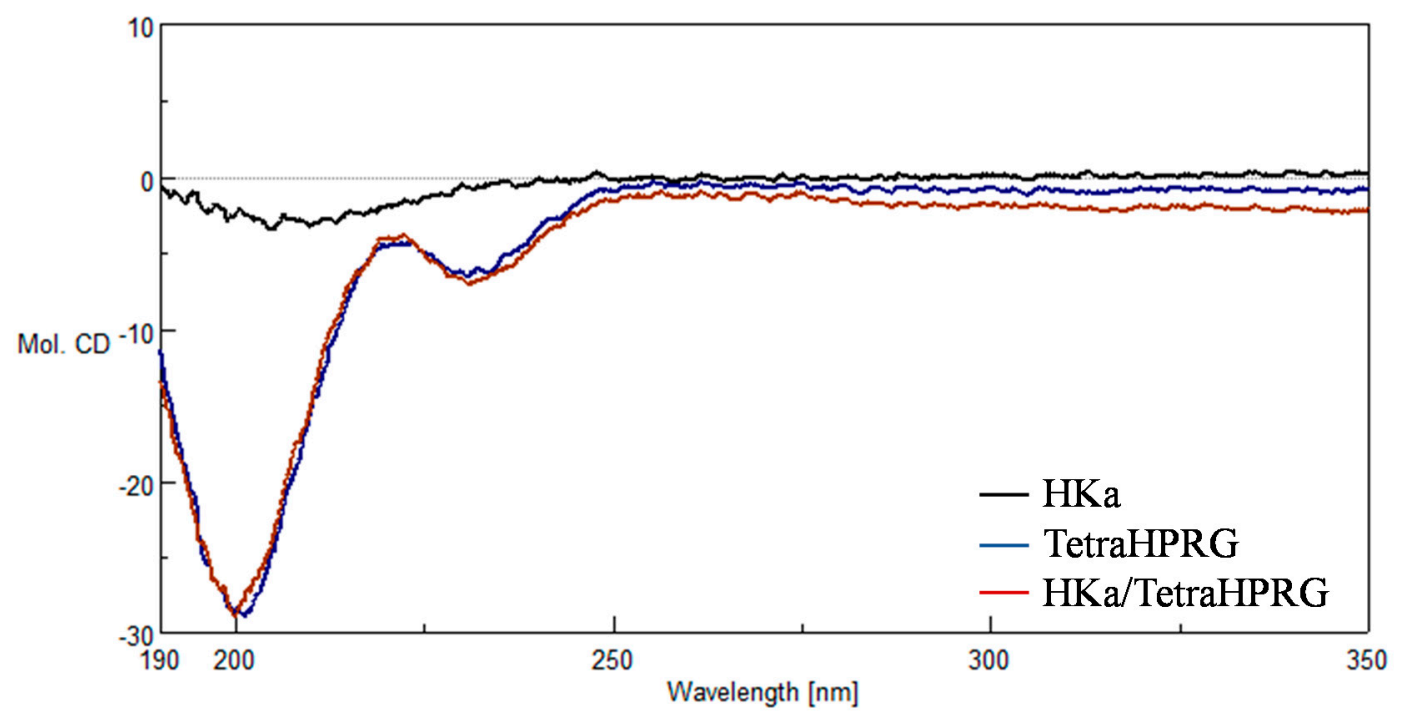

Figure 4. CD spectra Hka, TetraHPRG, and Hka/TetraHPRG in water $(\mathrm{pH}=7.5),[\mathrm{L}]=1 \times 10^{-5} \mathrm{M}$.

Both copper (II) and zinc (II) induced a reduction of dichroic signal of the HKa, although a prevalently random coil structure was maintained, as showed in Figure 5. No significant differences were observed increasing the metal ions equivalent at 2:1 compared to 1:1 spectra, but on the whole the zinc (II) addition was more effective than copper (II) in affecting the conformation of HKa.
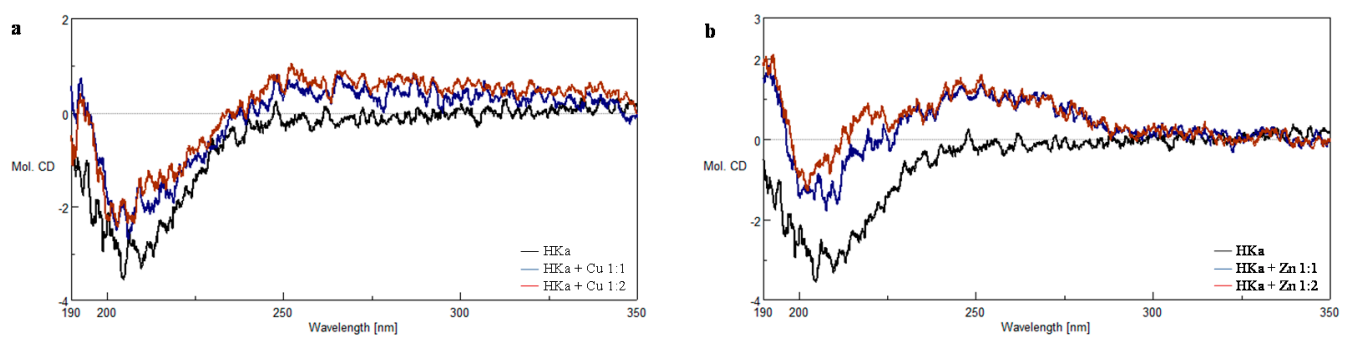

Figure 5. CD spectra of (a) copper(II) and (b) zinc(II) complexes with Hka in water $(\mathrm{pH}=7.5)$, at different mol equivalent of metal (metal to ligand molar ratio is 1:1 and 2:1; $[\mathrm{L}]=1 \times 10^{-5} \mathrm{M}$ ).

The conformational analysis of ternary systems showed the presence of two negative bands at about $195 \mathrm{nM}$ and $225 \mathrm{nM}$ and the spectra were very similar to that of TetraHPRG/ $\mathrm{Cu}^{2+}$ binary systems. Taking into account the strong difference in the dichroic signals between HKa and TetraHPRG, the signals of the binary systems, TetraHPRG/ $/ \mathrm{Cu}^{2+}$ and TetraHPRG/ $/ \mathrm{Zn}^{2+}$, were subtracted to those of ternary systems, $\mathrm{HKa} / \mathrm{TetraHPRG} / \mathrm{Cu}^{2+}$ and $\mathrm{HKa} / \mathrm{TetraHPRG} / \mathrm{Zn}^{2+}$, respectively (Figures S2 and S3). The difference spectra together with binary system $\mathrm{HKa} / \mathrm{Cu}^{2+}$ spectra are reported in Figure 6a. As observed, the differences spectra are not superimposable to that of binary systems, suggesting a dichroic contribute due to formation of an interaction between protein, peptide, and copper.

The resultant difference between the spectra HKa/TetraHPRG/ $/ \mathrm{n}^{2+}$ and TetraHPRG/ $\mathrm{Zn}^{2+}$ showed a CD profile completely different to that of $\mathrm{HKa} / \mathrm{Zn}^{2+}$ spectrum, evidencing a positive band at about $220 \mathrm{nM}$ (Figure $6 \mathrm{~b}$ ). Such behavior suggested that the intensity of dichroic signals of CD spectra was not only due only to the sum of the single contribute of $\mathrm{HKa} / \mathrm{Zn}^{2+}$ and TetraHPRG/ $\mathrm{Zn}^{2+}$ binary systems, but, as well as for copper, also to a contribute of the contemporary interaction between HKa, TetraHPRG and zinc. Furthermore, the interaction with the copper and zinc influenced the HKa conformational profile in a different way, suggesting a different binding modes in the two ternary systems. 

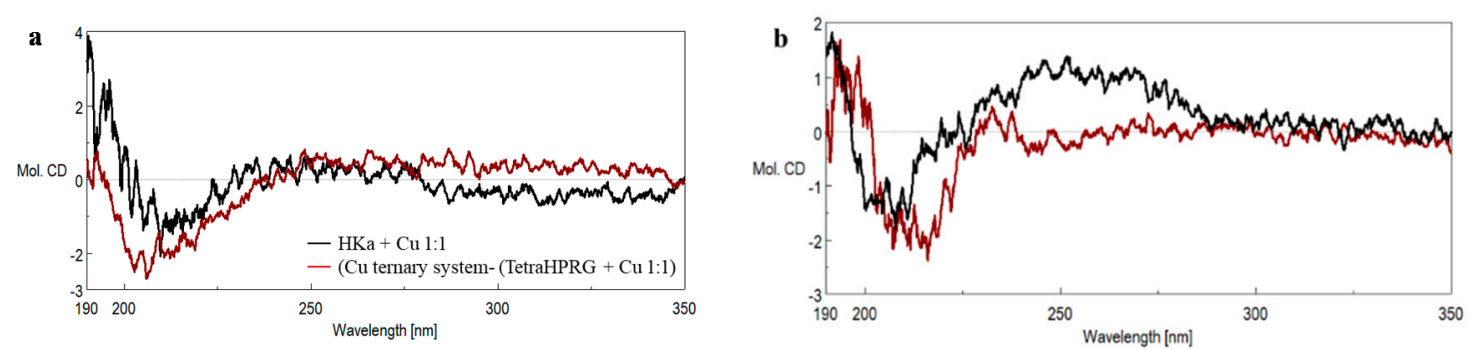

Figure 6. CD difference spectra of the (a) Hka/TetraHPRG/ $\mathrm{Cu}^{2+}$ ternary system minus CD spectra from TetraHPRG/Cu ${ }^{2+}$ systems and $\mathrm{CD}$ spectra of the $\mathrm{Hka} / \mathrm{Cu}^{2+}$ at 1:1 metal to ligand ratios and (b) $\mathrm{CD}$ difference spectra of the Hka/TetraHPRG/ $\mathrm{Zn}^{2+}$ ternary system minus normalized CD spectra from TetraHPRG/Zn ${ }^{2+}$ systems and CD spectra of the $\mathrm{Hka} / \mathrm{Zn}^{2+}$ at $1: 1$ metal to ligand ratios.

\section{2. $p H$ Effect}

The TetraHPRG is a sequence of the repeats rich in Pro and His residues [11] which may have a key role in the antiagiogenic activity [46]. Taking into account the pKa values of histidine, the binding properties of this domain are strongly influenced by electrostatic forces [47] that can be also influenced by the presence of metal ions, ionic strength and $\mathrm{pH}$ value.

To verify that tropomyosin binding assay has the sufficient sensitivity to appreciate the electrostatic contribution into interaction $\mathrm{HKa}^{*}$ /TetraHPRG/tropomyosin metal-mediated, we performed the ELISA assay at $\mathrm{pH}$ increasing only half unit of $\mathrm{pH}$ respect to standard experimental settings ( $\mathrm{pH}$ 7.5), in coincubation conditions. While at $\mathrm{pH} 7.5$ the metal promoted the binding of TetraHPRG with $\mathrm{HKa}^{*}$ (as reported in Figure 2), at pH 8.0 the metal reduced the interaction (Figure 7). As reported by Donate et al. [11], the H/P domain appeared to interact with tropomyosin, negatively charged, only when the $\mathrm{H} / \mathrm{P}$ domain acquired a positive charge either, through binding $\mathrm{Zn}^{2+}$ via neutral His residues or by direct protonation of histidines induced under mild acidic conditions [14]; this suggests a large electrostatic contribution to the binding. The results reported in Figure 7, confirmed the involvement of histidine residues in the interaction between TetraHPRG and tropomyosin mediated by zinc(II) and suggested a similar behavior also for copper(II) ion.

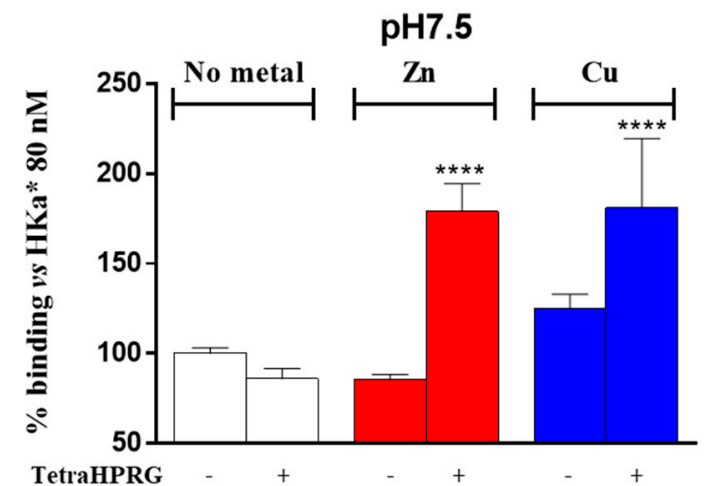

(a)

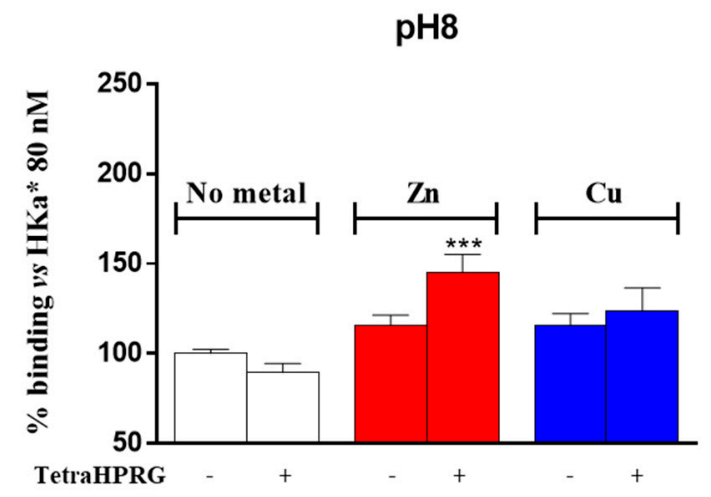

(b)

Figure 7. Percentage of $\mathrm{HKa}^{*}$ binding to tropomyosin at different $\mathrm{pH}$. $\mathrm{HKa}^{*}(80 \mathrm{nM})$ in MOPS $\mathrm{pH} 7.5$ (a) or $\mathrm{pH} 8.0(\mathbf{b})$, in presence or not of $25 \mathrm{uM}$ of TetraHPRG and in presence or not of $\mathrm{CuSO}_{4}$ or $\mathrm{ZnCl}_{2}$ $(10 \mu \mathrm{M})$. Data are the mean \pm SEM of three different experiments performed in triplicate. Statistically significant differences are indicated with ${ }^{* * *}=p<0.001$ and ${ }^{* * * *}=p<0.0001$ vs. HKa $80 \mathrm{nM}$ (One-Way ANOVA + Dunnett's test). 


\subsection{TetraHPRG Effect in "Pre-Treatment"}

To better elucidate the effect of TetraHPRG on HKa* binding to tropomyosin, the order of molecules addition was modified, depositing the peptide directly on the plate with tropomyosin, after the blocking step and before the incubation step of HKa*. This modality that we defined as pre-treatment (see Scheme 1) allowed to isolate the single components involved in the binding phenomena, respect to the coincubation where all molecules are mixed together.

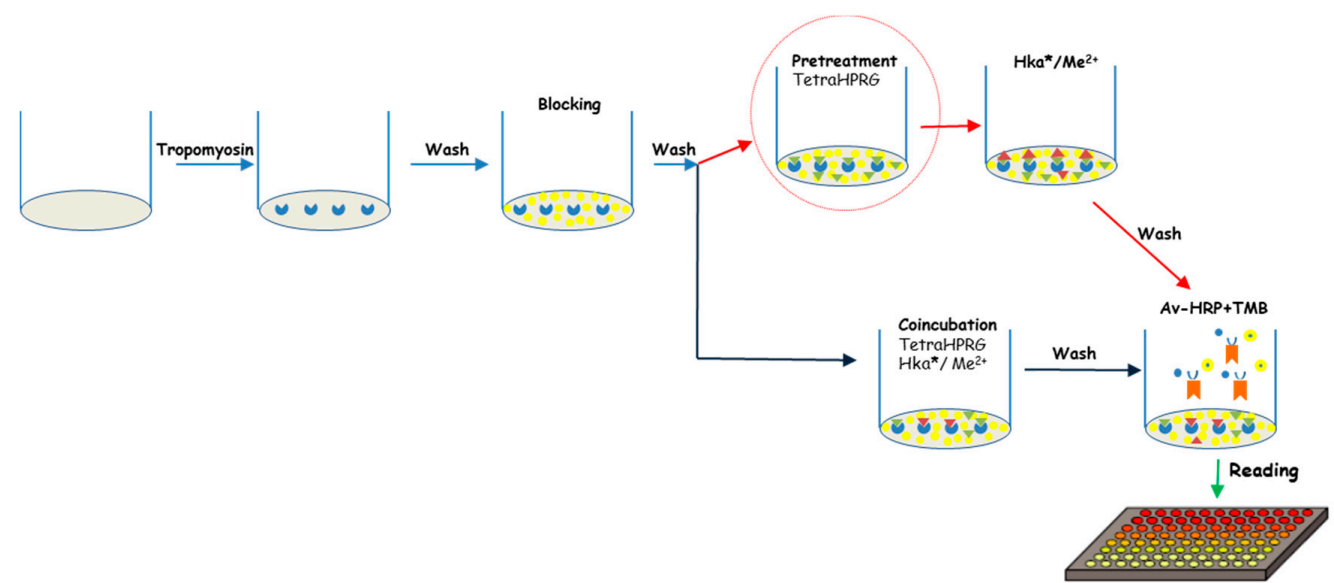

Scheme 1. ELISA assay steps in conditions of coincubation (down) and pre-treatment (up). $\mathrm{HKa}^{*}$ (Kininogen activated), $\mathrm{Me}^{2+}\left(\mathrm{Cu}^{2+}\right.$ or $\left.\mathrm{Zn}^{2+}\right), \mathrm{Av}-\mathrm{HRP}$ (avidin conjugated with horseradish peroxidase), TMB (3,3-5,5-tetramethylbenzidine).

As first evidence of the modifying ELISA conditions in pre-treatment and in absence of metals, the TetraHPRG at $25 \mu \mathrm{M}$ overturns its competitive effect, and surprisingly, the levels of HKa* bound were increased of about $+50 \%$. This effect was positively strengthened by the presence of $\mathrm{Cu}^{2+}$ or $\mathrm{Zn}^{2+}$ ions, as can be observed by the high intensity of $\mathrm{HKa}^{*}$ detected (Figure 8, left group); this result may be due to a favorite formation of a ternary complex tropomyosin-TetraHPRG-HKa*, whose existence seems to be supported by $\mathrm{CD}$ results.

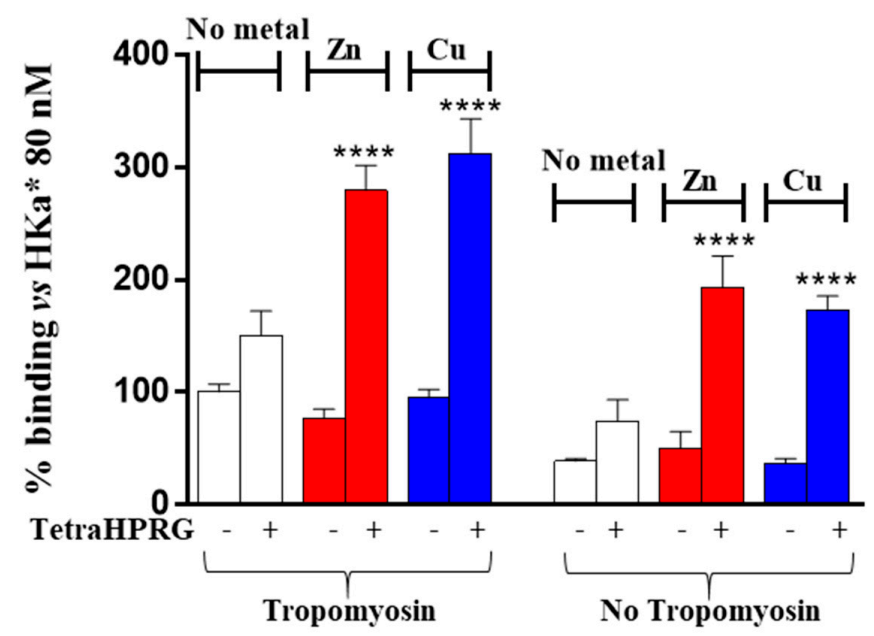

Figure 8. \% Binding of $\mathrm{HKa}^{*}$ to plate previously coated with tropomyosin (left group) or not (right). After tropomyosin the plate has been blocked with milk $5 \%$ and the pretreated with TetraHPRG at $25 \mu \mathrm{M}$ before to the addition of $\mathrm{HKa}^{*}(80 \mathrm{nM})$ in MOPS $\mathrm{pH} 7.5$ in presence or not of $\mathrm{CuSO}_{4}$ or $\mathrm{ZnCl}_{2}(10 \mu \mathrm{M})$. Data are the mean \pm SEM of three different experiments performed in triplicate. Statistically significant differences are indicated with ${ }^{* * *}=p<0.0001$ vs. HKa $80 \mathrm{nM}$ (One-Way ANOVA + Dunnett's test). 
Successively, observing that the TetraHPRG deposition on a plate (in the pretreatment modality) increased significantly the adhesivity to $\mathrm{HKa}^{*}$, we decided to evaluate if this adhesiveness was mediated by the tropomyosin or by the "blocked surface". For this purpose, assays in absence and in presence of tropomyosin, using milk protein as blocking step, were performed. Although in the presence of tropomyosin the levels of $\mathrm{HKa}^{*}$ bound were higher (about double) respect to corresponding samples in absence of tropomyosin, the binding trend was comparable (Figure 8, right group). The addition of each metal ions induced a similar increase in the percentage of $\mathrm{HKa}^{*}$ bound, confirming that both zinc and copper ions were crucial in the interaction between TetraHPRG and HKa*.

\section{Discussion}

The HPRG protein is a well-known angiogenic modulator, although the mechanisms of its anti-angiogenic activity are not fully understood. An hypothesis, provided by in vitro and in vivo studies [11], points to the binding of H/P reach domain of HPRG with tropomyosin, a protein normally found inside cell where stabilizes actin filaments of cytoskeleton and expressed by endothelial cell during angiogenic process. This interaction activates anti-angiogenic signaling transduction pathways. In a similar way, the high molecular weight kininogen (HKa) inhibits angiogenesis [13], involving a direct binding to tropomyosin. The HKa-D5 (HKa domain 5) and the H/P domain of HPRG, resulted to have a similar binding to heparin and metals, and an abundance of positive charges. The evidence that $\mathrm{H} / \mathrm{P}$ peptide blocks HKa binding to tropomyosin support that HPRG and HKa share the same receptor. Therefore, a comparison between HKa and the peptide TetraHPRG ability to bind tropomyosin could provide useful information, in particular on the role of copper and zinc ions in the tumor microenvironment. The effect of zinc binding to ternary system Hka-TetraHPRG-tropomyosin has been extensively studied and although copper shares with zinc similar coordination binding environment, at the best of our knowledge, no data have been reported about the role of copper in such system.

TetraHPRG, (Ac-(HHPHG) $)_{4}-\mathrm{NH}_{2}$ ) a blocked tetramer at $\mathrm{N}$ - and C-termini was synthesized as an effective HPRG mimic system, able to compete with the whole protein in binding to the HUVEC tropomyosin and heparin sulfate proteoglycan receptors [11]. Differently from assays reported in literature, that used chicken tropomyosin, in this work human tropomyosin was employed.

In experimental conditions of the present work, ELISA assays show that, at $\mathrm{pH} 7.5$, zinc ions reduced the HKa-tropomyosin binding, while copper increased it. CD spectra of $\mathrm{HKa}$ after the addition of metal ions show that zinc induces a major perturbation of HKa conformation. This is in agreement with the conformational changes reported for the entire HKa molecule due to the zinc binding to the HKa-D5 [28] domain. Such effect has not been reported for other metals and in particular for copper.

The conformation of TetraHPRG is affected by both zinc and copper ion. Moreover, the potentiometric titrations suggested that peptide binds tightly zinc and the main species at physiological $\mathrm{pH}$, is $\mathrm{ZnLH}_{4}$, in which the metal coordination environment involves four imidazole nitrogen atoms. Increasing the $\mathrm{pH}$, the deprotonation of amide nitrogen atoms should also occur. However, this is suggested only by the different $\mathrm{pKa}$ values for the zinc complex in comparison to the free ligand, as spectroscopic data are not available for $\mathrm{d}^{10}$ electronic configuration of $\mathrm{Zn}^{2+}$.

CD conformational analysis showed that TetraHPRG spectrum features underlined an equilibrium between PPII and random coil conformations. The TetraHPRG peptide is able to partially maintain the conformation PPII observed for this domain in the whole protein [27]. The addition of metal ions affected the peptide conformation, suggesting the presence of a turn conformation induced by copper or zinc binding. The CD spectra bands at $260 \mathrm{nM}$ and $300 \mathrm{nM}$, typical of ligand to copper(II) charge transfer of imidazole and amide nitrogen atoms, confirmed the coordination environment of metal as suggested by potentiometric measurements at physiological $\mathrm{pH}$ [27].

In the presence of TetraHPRG, copper ions, as well as zinc ions, promote the binding between $\mathrm{HKa}$ and tropomyosin. Furthermore, this phenomenon is confirmed by the ternary system formation TetraHPRG-HKa-metal (zinc or copper), whose existence is corroborated by conformational changes induced by metal coordination $[48,49]$. In fact, the CD spectrum of a mixture of HKa and TetraHPRG, 
is the result sum of these separate components, suggesting the absence of a direct interaction. Interestingly, the addition of metal ions resulted into significant variations in the spectra profiles not simply attributable to the formation of the metal-TetraHPRG complex. In differences spectra, the appearance of new bands, suggests the formation of a ternary complex system between HKa, peptide and metal. This can explain the increase in the binding to tropomyosin of HKa in the contemporary presence of TetraHPRG and metal ions. In ternary systems the interaction of zinc is more effective than copper ions suggesting a potential different coordination modes.

Interestingly, a slight $\mathrm{pH}$ variation influenced the HKa-TetraHPRG-tropomyosin binding. The activity of TetraHPRG is related to the presence of histidine residues for both, metal binding and charge effects. At $\mathrm{pH} 8.0$ the amount of [CuL] increase, and in this species there are two deprotonated amide nitrogen atoms, that neutralizes the positive charges of metal. These combined effects may explain the drastic reduction of $\mathrm{HKa}^{*}$ bound to tropomyosin at $\mathrm{pH} 8.0$ compared to $\mathrm{pH} 7.5$ and confirm the involvement of charged histidine residues in the interaction between TetraHPRG and tropomyosin as suggested in a previous work [11].

Intriguingly, in pre-treatment condition the TetraHPRG overturns its competitive effect, and the levels of $\mathrm{HKa}^{*}$ bound increase of about $+50 \%$. This effect is positively strengthened by the presence of $\mathrm{Cu}^{2+}$ or $\mathrm{Zn}^{2+}$ ions.

This condition can also be attributable to a favorite formation of a ternary complex tropomyosin-TetraHPRG-HKa*. Moreover, we found that although in the presence of tropomyosin the levels of $\mathrm{HKa}^{*}$ bound were higher respect to corresponding samples in absence of tropomyosin, the pattern of binding was comparable. In a similar way, the addition of both metal ions induced an increase of percentage of $\mathrm{HKa}^{*}$ bound, confirming that metal ions were crucial in the binding between TetraHPRG and HKa*.

The experimental conditions used in this study pinpoints the property of the interaction between TetraHPRG/HKa with tropomyosin, highlighting how it may be strongly influenced by the presence of metal ions, ionic strength, and $\mathrm{pH}$ value. Specifically, TetraHPRG and HKa antiangiogenic property is enhanced by the presence of metal ions, promoting the formation of a ternary complex among proteins, peptide and metal ions. This effect suggests that copper, like zinc, may mediate the binding of HPRG to the tropomyosin exposed on the endothelial cell surface and modulate its antiangiogenic activity. Thus, the use of TetraHPRG could take advantage of the high copper level typical of tumor microenvironment.

\section{Materials and Methods}

\subsection{Proteins, Peptides, and Materials}

Human cardiac tropomyosin was purchased from Alpha Diagnostics; HKa was obtained from Enzyme Research Laboratories (Swansea, UK). HKa was biotinylated using EZ-Link Sulfo-NHS-LC-biotin (Thermo, Waltham, Massachusetts, USA) following the manufacturer's instructions.

The peptide [Ac- $(\mathrm{GHHPH})_{4}-\mathrm{G}-\mathrm{NH}_{2}$ ] (TetraHPRG) has been synthesized in the N-acetylated and $\mathrm{C}$-amidated form to mimic more properly its character of a protein internal fragment. The synthesis was carried out by means of solid phase peptide synthesis as previously reported [27]. Avidin-horseradish peroxidase (Av-HRP) was acquired from Sigma (Saint Louis, Missouri, USA) and 3,3-5,5-tetramethylbenzidine (TMB) was purchased from Enzo life (Farmingdale, New York, USA).

\subsection{ELISA Assay}

Human cardiac tropomyosin (Alpha Diagnostics, San Antonio, TX, USA) was dissolved in TBS (Tris $50 \mathrm{mM} \mathrm{pH} 7.5+\mathrm{NaCl} 140 \mathrm{mM}$ ) and $200 \mathrm{ng}$ were added/well in a 96-well high binding polystyrene assay plate (Santa Cruz, Dallas, Texas, USA), and then incubated for $6 \mathrm{~h}$ at room temperature. The plate was washed with TBS-T (TBS + Tween20 0.05\%) and blocked with not fat milk (5\%) in TBS, overnight. Then, $80 \mathrm{nM}$ biotinilated $\mathrm{HKa}\left(\mathrm{HKa}^{*}\right)$ was added in the presence of $10 \mu \mathrm{M}$ metal ions $\left(\mathrm{ZnCl}_{2} / \mathrm{CuSO}_{4}\right)$ 
together with TetraHPRG $25 \mu \mathrm{M}$, in MOPS $10 \mathrm{mM}$ at pH 7.5 and 8.0, and incubated for $2 \mathrm{~h}$ at RT. The unbound $\mathrm{HKa}^{*}$ was then removed washing five times with the TBS-T buffer. Then bound $\mathrm{HKa}^{*}$ was detected using avidin-horseradish peroxidase (Av-HRP) and the chromogenic substrate 3,3-5,5-tetramethylbenzidine (TMB) at 450nM.

\subsection{Spectroscopy}

CD spectra were obtained at $25^{\circ} \mathrm{C}$ under a constant flow of nitrogen on a Jasco model 1500 spectropolarimeter at a scan rate of $50 \mathrm{nM} \mathrm{min}^{-1}$ and a resolution of $0.1 \mathrm{nM}$. The path length was $1 \mathrm{~cm}$, in the 190-350 nM range. The spectra were recorded as an average of 10 or 20 scans (data points 1601). Calibration of the instrument was performed with a $0.06 \%$ solution of ammonium camphorsulfonate in water. All the solutions were freshly prepared using MOPS $10 \mathrm{mM}$ at pH 7.5. CD spectra were acquired by using $1.0 \times 10^{-5} \mathrm{M}$ peptide concentration at different metal to ligand ratios 1:1 and 2:1 in the presence or not of $1.3 \times 10^{-8} \mathrm{M}$ kininogen $(\mathrm{HKa})$. The results are reported as $\Delta \varepsilon$ (molar dichroic coefficient) in $\mathrm{M}^{-1}$.

\subsection{Potentiometric Titrations}

Potentiometric titrations were performed on automatic instrument Titrando 905 using a combined glass-Ag/AgCl electrode (Metrohm, Herisau, Switzerland). Aqueous solutions of samples (2.0 mL) were kept under an argon atmosphere and at $298 \mathrm{~K}$ by means of a thermostat. Other details on the electrode calibration have been previously reported [50]. In all solutions, the ionic strength was fixed at $0.1 \mathrm{M}$ by adding $\mathrm{KNO}_{3}$. $\mathrm{KOH} 0.1 \mathrm{M}$ was used to titrate solutions containing either the peptides only or the peptide with $\mathrm{Zn}^{2+}$. The peptide concentrations employed were $1 \times 10^{-3} \mathrm{M}$. At least three independent titrations were performed. Starting $\mathrm{pH}$ value was adjusted to 2.4 by adding HNO3 $0.2 \mathrm{~m}$ and measurements were carried out up to $\mathrm{pH}$ 8.5. Metal ion/ligand ratios between 0.9:1 and 2.2:1 were employed. The data were analyzed by using HYPERQUAD 2003 program [51] and species distribution as a function of $\mathrm{pH}$ was obtained by using Hyss program [52].

\subsection{Statistical Analysis}

Graph-Pad Prism (Version 7.00) was used for data analysis and graphic presentation. Data were reported as the mean \pm SEM of at least three or two different experiments. Statistical analyses were performed using a one-way ANOVA study followed by the Dunnett test for repeated measurements. Differences were considered statistically significant when $p<0.05$.

Supplementary Materials: The following are available online at http://www.mdpi.com/1422-0067/21/24/9343/s1, Table S1: Protonation constants of TetraHPRG; Figure S1: Species distribution diagram for the $\mathrm{Zn}^{2+}$ complexes with TetraHPRG with M/L molar ratio 2:1.; Figure S2: CD spectra of copper(II) complexes with Hka, TetraHPRG and of ternary systems (Hka/TetraHPRG/Cu ${ }^{2+}$ :; Figure S3: CD spectra of zinc(II) complexes with Hka, TetraHPRG and ternary systems (Hka/TetraHPRG/Zn(II)).

Author Contributions: Conceptualization, A.M.S. and D.L.M.; methodology, A.M.S. and G.G.; peptide synthesis A.M.; investigation, A.M., S.Z. and G.G.; writing-original draft preparation, A.M.S., G.G. and D.L.M.; writing-review and editing, D.L.M., S.Z. and G.G; funding acquisition, D.L. All authors have read and agreed to the published version of the manuscript.

Funding: This work is supported by the University of Pisa under the "PRA-Progetti di Ricerca di Ateneo" Institutional Research Grants-Project no. PRA_2020_58 “Agenti innovativi e nanosistemi per target molecolari nell'ambito dell'oncologia di precisione" and under the "Rating Ateneo 2019-2020". The work is also supported by Beneficentia Stiftung Foundation, Vaduz (BEN2019/48).

Acknowledgments: D.L. gratefully acknowledges University Consortium for Research in the Chemistry of Metal ions in Biological Systems (CIRCMSB).

Conflicts of Interest: The authors declare no conflict of interest. 


\section{References}

1. Lijnen, H.R.; Hoylaerts, M.; Collen, D. Heparin binding properties of human histidine-rich glycoprotein. Mechanism and role in the neutralization of heparin in plasma. J. Biol. Chem. 1983, 258, 3803-3808.

2. Poon, I.K.H.; Patel, K.K.; Davis, D.S.; Parish, C.R.; Hulett, M.D. Histidine-rich glycoprotein: The Swiss Army knife of mammalian plasma. Blood 2011, 117, 2093-2101. [CrossRef]

3. Lijnen, H.R.; Hoylaerts, M.; Collen, D. Isolation and characterization of a human plasma protein with affinity for the lysine binding sites in plasminogen. Role in the regulation of fibrinolysis and identification as histidine-rich glycoprotein. J. Biol. Chem. 1980, 255, 10214-10222.

4. Leung, L.L.K. Interaction of histidine-rich glycoprotein with fibrinogen and fibrin. J. Clin. Investig. 1986, 77, 1305-1311. [CrossRef]

5. Gorgani, N.N.; Parish, C.R.; Altin, J.G. Differential binding of histidine-rich glycoprotein (HRG) to human IgG subclasses and IgG molecules containing $\mathrm{k}$ and $\lambda$ light chains. J. Biol. Chem. 1999, 274, 29633-29640. [CrossRef] [PubMed]

6. Morgan, W.T. Human serum histidine-rich glycoprotein. I. Interactions with heme, metal ions and organic ligands. BBA Protein Struct. 1978, 535, 319-333. [CrossRef]

7. Ranieri-Raggi, M.; Moir, A.J.G.; Raggi, A. The role of histidine-proline-rich glycoprotein as zinc chaperone for skeletal muscle AMP deaminase. Biomolecules 2014, 4, 474-497. [CrossRef]

8. Ronca, F.; Raggi, A. Structure-function relationships in mammalian histidine-proline-rich glycoprotein. Biochimie 2015, 118, 207-220. [CrossRef] [PubMed]

9. Gunning, P.; O'Neill, G.; Hardeman, E. Tropomyosin-based regulation of the actin cytoskeleton in time and space. Physiol. Rev. 2008, 88, 1-35. [CrossRef]

10. Jones, A.L.; Hulett, M.D.; Parish, C.R. Histidine-rich glycoprotein: A novel adaptor protein in plasma that modulates the immune, vascular and coagulation systems. Immunol. Cell Biol. 2005, 83, 106-118. [CrossRef] [PubMed]

11. Doñate, F.; Juarez, J.C.; Guan, X.; Shipulina, N.V.; Plunkett, M.L.; Tel-Tsur, Z.; Shaw, D.E.; Morgan, W.T.; Mazar, A.P. Peptides derived from the histidine-proline domain of the histidine-proline-rich glycoprotein bind to tropomyosin and have antiangiogenic and antitumor activities. Cancer Res. 2004, 64, 5812-5817. [CrossRef] [PubMed]

12. Dantas, E.; Erra Díaz, F.; Pereyra Gerber, P.; Varese, A.; Jerusalinsky, D.A.; Epstein, A.L.; García Rivello, H.J.; del Valle Jaén, A.; Pandolfi, J.B.; Ceballos, A.; et al. Histidine-Rich Glycoprotein Inhibits HIV-1 Infection in a pH-Dependent Manner. J. Virol. 2018, 93. [CrossRef] [PubMed]

13. Zhang, J.C.; Doñate, F.; Qi, X.; Ziats, N.P.; Juarez, J.C.; Mazar, A.P.; Pang, Y.P.; McCrae, K.R. The antiangiogenic activity of cleaved high molecular weight kininogen is mediated through binding to endothelial cell tropomyosin. Proc. Natl. Acad. Sci. USA 2002, 99, 12224-12229. [CrossRef] [PubMed]

14. Guan, X.; Juarez, J.C.; Qi, X.; Shipulina, N.V.; Shaw, D.E.; Morgan, W.T.; McCrae, K.R.; Mazar, A.P.; Doñate, F. Histidine-Proline Rich Glycoprotein (HPRG) binds and transduces anti-angiogenic signals through cell surface tropomyosin on endothelial cells. Thromb. Haemost. 2004, 92, 403-412. [CrossRef] [PubMed]

15. Gorodetsky, R.; Mou, X.; Blankenfeld, A.; Marx, G. Platelet multielemental composition, lability, and subcellular localization. Am. J. Hematol. 1993, 42, 278-283. [CrossRef]

16. Ishida, T. Anti-Cancer Effects of Zinc (II) Ion in Tumor Formation and Growth, Proliferation, Metastasis and DNA Damage. In Degenerative Intellectual \& Developmental Disabilities; Crimson Publishers, LLC: New York, NY, USA, 2017; pp. 1-8.

17. Denoyer, D.; Masaldan, S.; La Fontaine, S.; Cater, M.A. Targeting copper in cancer therapy: “Copper That Cancer". Metallomics 2015, 7, 1459-1476. [CrossRef]

18. La Mendola, D.; Giacomelli, C.; Rizzarelli, E. Intracellular Bioinorganic Chemistry and Cross Talk Among Different -Omics. Curr. Top. Med. Chem. 2016, 16, 3103-3130. [CrossRef]

19. Schwartz, M.K. Role of Trace Elements in Cancer. Cancer Res. 1975, 35, 3481-3487.

20. Gupte, A.; Mumper, R.J. Elevated copper and oxidative stress in cancer cells as a target for cancer treatment. Cancer Treat. Rev. 2009, 35, 32-46. [CrossRef]

21. Kuo, H.W.; Chen, S.F.; Wu, C.C.; Chen, D.R.; Lee, J.H. Serum and Tissue Trace Elements in Patients with Breast Cancer in Taiwan. Biol. Trace Element Res. 2002, 89, 1-11. [CrossRef] 
22. Sharma, K.; Mittal, D.K.; Kesarwani, R.C.; Kamboj, V.P. Chowdhery Diagnostic and prognostic significance of serum and tissue trace elements in breast malignancy. Indian J. Med. Sci. 1994, 48, 227-232. [PubMed]

23. Zowczak, A.; Iskra, M.; Torlin, L.; Cofta, S. Analysis of Serum Copper and Zinc Concentrations in Cancer Patients. Biol. Trace Elem. Res. 2001, 82,1-8. [CrossRef]

24. Gupta, S.K.; Shukla, V.K.; Vaidya, M.P.; Roy, S.K.; Gupta, S. Serum and tissue trace elements in colorectal cancer. J. Surg. Oncol. 1993, 52, 172-175. [CrossRef] [PubMed]

25. Finney, L.; Mandava, S.; Ursos, L.; Zhang, W.; Rodi, D.; Vogt, S.; Legnini, D.; Maser, J.; Ikpatt, F.; Olopade, O.I.; et al. $\mathrm{X}$-ray flourescence microscopy reveals large-scale relocalization and extracellular translocation of cellular copper during angiogenesis. Proc. Natl. Acad. Sci. USA 2007, 104, 2247-2252. [CrossRef]

26. Finney, L.; Vogt, S.; Fukai, T.; Glesne, D. Copper and angiogenesis: Unravelling a relationship key to cancer progression. Clin. Exp. Pharmacol. Physiol. 2009, 36, 88-94. [CrossRef]

27. Magrì, A.; Grasso, G.; Corti, F.; Finetti, F.; Greco, V.; Santoro, A.M.; Sciuto, S.; La Mendola, D.; Morbidelli, L.; Rizzarelli, E. Peptides derived from the histidine-proline rich glycoprotein bind copper ions and exhibit anti-angiogenic properties. Dalt. Trans. 2018, 47, 9492-9503. [CrossRef]

28. Herwald, H.; Mörgelin, M.; Svensson, H.G.; Sjöbring, U. Zinc-dependent conformational changes in domain D5 of high molecular mass kininogen modulate contact activation. Eur. J. Biochem. 2001, 268, 396-404. [CrossRef]

29. Johnson, W.C., Jr. Methods of Biochemical Analysis; Wiley-Interscience: Hoboken, NJ, USA, 1985; Volume 31, ISBN 0471821772.

30. Woody, R.W. Circular Dichroism. Methods Enzymol. 1995, 246, 34-71. [CrossRef]

31. Woody, R.W. Theory of Circular Dichroism of Proteins. In Circular Dichroism and the Conformational Analysis of Biomolecules; Springer: New York, NY, USA, 1996; pp. 25-67.

32. Corrêa, D.; Henrique, C.; Ramos, I.; Corrêa, D.H.A.; Ramos, C.H.I. The use of circular dichroism spectroscopy to study protein folding, form and function Protein stability, folding and misfolding View project Structure and function of molecular chaperones View project The use of circular dichroism spectroscopy to study protein folding, form and function. Afr. J. Biochem. Res. 2009, 3, 164-173.

33. La Mendola, D.; Bonomo, R.P.; Caminati, S.; Di Natale, G.; Emmi, S.S.; Hansson, Ö.; Maccarrone, G.; Pappalardo, G.; Pietropaolo, A.; Rizzarelli, E. Copper(II) complexes with an avian prion N-terminal region and their potential SOD-like activity. J. Inorg. Biochem. 2009, 103, 195-204. [CrossRef]

34. Woody, R.W. Circular dichroism spectrum of peptides in the poly(Pro)II conformation. J. Am. Chem. Soc. 2009, 131, 8234-8245. [CrossRef] [PubMed]

35. Borza, D.B.; Tatum, F.M.; Morgan, W.T. Domain structure and conformation of histidine-Proline-rich glycoprotein. Biochemistry 1996, 35, 1925-1934. [CrossRef] [PubMed]

36. La Mendola, D.; Magrì, A.; Campagna, T.; Campitiello, M.A.; Raiola, L.; Isernia, C.; Hansson, Ö.; Bonomo, R.P.; Rizzarelli, E. A Doppel $\alpha$-Helix Peptide Fragment Mimics the Copper(II) Interactions with the Whole Protein. Chem. A Eur. J. 2010, 16, 6212-6223. [CrossRef] [PubMed]

37. Kállay, C.; Ôsz, K.; Dávid, A.; Valastyán, Z.; Malandrinos, G.; Hadjiliadis, N.; Sóvágó, I. Zinc(ii) binding ability of tri-, tetra- and penta-peptides containing two or three histidyl residues. Dalton Trans. 2007, 36, 4040-4047. [CrossRef]

38. La Mendola, D.; Magrì, A.; Santoro, A.M.; Nicoletti, V.G.; Rizzarelli, E. Copper(II) interaction with peptide fragments of histidine-proline-rich glycoprotein: Speciation, stability and binding details. J. Inorg. Biochem. 2012, 111, 59-69. [CrossRef]

39. Hecel, A.; Wątły, J.; Rowińska-Żyrek, M.; Świątek-Kozłowska, J.; Kozłowski, H. Histidine tracts in human transcription factors: Insight into metal ion coordination ability. J. Biol. Inorg. Chem. 2018, 23, 81-90. [CrossRef]

40. Valensin, D.; Szyrwiel, Ł.; Camponeschi, F.; Rowińska-Żyrek, M.; Molteni, E.; Jankowska, E.; Szymańska, A.; Gaggelli, E.; Valensin, G.; Kozlowski, H. Heteronuclear and homonuclear $\mathrm{Cu}^{2+}$ and $\mathrm{Zn}^{2+}$ complexes with multihistidine peptides based on zebrafish prion-like protein. Inorg. Chem. 2009, 48, 7330-7340. [CrossRef]

41. Pushie, M.J.; Nienaber, K.H.; McDonald, A.; Millhauser, G.L.; George, G.N. Combined EXAFS and DFT Structure Calculations Provide Structural Insights into the 1:1 Multi-Histidine Complexes of $\mathrm{Cu}^{\mathrm{II}}, \mathrm{Cu}^{\mathrm{I}}$, and $\mathrm{Zn}^{\mathrm{II}}$ with the Tandem Octarepeats of the Mammalian Prion Protein. Chem. A Eur. J. 2014, 20, 9770-9783. [CrossRef] 
42. Jakab, N.I.; Jancsó, A.; Gajda, T.; Gyurcsik, B.; Rockenbauer, A. Copper(II), nickel(II) and zinc(II) complexes of $\mathrm{N}$-acetyl-His-Pro-His-His-NH2: Equilibria, solution structure and enzyme mimicking. J. Inorg. Biochem. 2008, 102, 1438-1448. [CrossRef]

43. Travaglia, A.; La Mendola, D.; Magrì, A.; Pietropaolo, A.; Nicoletti, V.G.; Grasso, G.; Malgieri, G.; Fattorusso, R.; Isernia, C.; Rizzarelli, E. Zinc(II) interactions with brain-derived neurotrophic factor N-terminal peptide fragments: Inorganic features and biological perspectives. Inorg. Chem. 2013, 52, 11075-11083. [CrossRef]

44. Pietropaolo, A.; Magrì, A.; Greco, V.; Losasso, V.; La Mendola, D.; Sciuto, S.; Carloni, P.; Rizzarelli, E. Binding of $\mathrm{Zn}(\mathrm{II})$ to Tropomyosin Receptor Kinase A in Complex with Its Cognate Nerve Growth Factor: Insights from Molecular Simulation and in Vitro Essays. ACS Chem. Neurosci. 2018, 9, 1095-1103. [CrossRef]

45. Grasso, G.; Magrì, A.; Bellia, F.; Pietropaolo, A.; La Mendola, D.; Rizzarelli, E. The copper(II) and zinc(II) coordination mode of HExxH and HxxEH motif in small peptides: The role of carboxylate location and hydrogen bonding network. J. Inorg. Biochem. 2014, 130, 92-102. [CrossRef]

46. Juarez, J.C.; Guan, X.; Shipulina, N.V.; Plunkett, M.L.; Parry, G.C.; Shaw, D.E.; Zhang, J.-C.; Rabbani, S.A.; McCrae, K.R.; Mazar, A.P.; et al. Histidine-Proline-rich Glycoprotein Has Potent Antiangiogenic Activity Mediated through the Histidine-Proline-rich Domain. Cancer Res. 2002, 62, 62.

47. Harrison, J.S.; Higgins, C.D.; O’Meara, M.J.; Koellhoffer, J.F.; Kuhlman, B.A.; Lai, J.R. Role of electrostatic repulsion in controlling $\mathrm{pH}$-dependent conformational changes of viral fusion proteins. Structure 2013, 21, 1085-1096. [CrossRef] [PubMed]

48. Driller, R.; Ballaschk, M.; Schmieder, P.; Uchanska-Ziegler, B.; Ziegler, A.; Loll, X.B. Metal-triggered conformational reorientation of a self-peptide bound to a disease-associated HLA-B ${ }^{* 27}$ subtype. JBC 2019, 294, 13269-13279. [CrossRef] [PubMed]

49. Liu, D.; Seuthe, A.B.; Ehrler, O.T.; Zhang, X.; Wyttenbach, T.; Hsu, J.F.; Bowers, M.T. Oxytocin-receptor binding: Why divalent metals are essential. J. Am. Chem. Soc. 2005, 127, 2024-2025. [CrossRef]

50. La Mendola, D.; Magrì, A.; Hansson, O.; Bonomo, R.P.; Rizzarelli, E. Copper(II) complexes with peptide fragments encompassing the sequence 122-130 of human doppel protein. J. Inorg. Biochem. 2009, 103, 758-765. [CrossRef]

51. Gans, P.; Sabatini, A.; Vacca, A. Investigation of equilibria in solution. Determination of equilibrium constants with the HYPERQUAD suite of programs. Talanta 1996, 43, 1739-1753. [CrossRef]

52. Alderighi, L.; Gans, P.; Ienco, A.; Peters, D.; Sabatini, A.; Vacca, A. Hyperquad simulation and speciation (HySS): A utility program for the investigation of equilibria involving soluble and partially soluble species. Coord. Chem. Rev. 1999, 184, 311-318. [CrossRef]

Publisher's Note: MDPI stays neutral with regard to jurisdictional claims in published maps and institutional affiliations.

(C) 2020 by the authors. Licensee MDPI, Basel, Switzerland. This article is an open access article distributed under the terms and conditions of the Creative Commons Attribution (CC BY) license (http://creativecommons.org/licenses/by/4.0/). 